\title{
PELAKU PEDOFILIA \\ (Tinjauan Dari Faktor Penyebab dan Aspek Dinamika Psikologis)
}

\author{
Oleh : \\ Pambudi Rahardjo ${ }^{1}$ \\ Kaniya Puri ${ }^{2}$
}

\begin{abstract}
This study aims to find out the psychological dynamics in pedophiles. The focus of research is the factors causing pedophile behavior in perpetrators. This study uses a qualitative method with a case study approach. The results showed that the perpetrator was a person known by the victim, namely the neighbor and the teacher. In general, the three participants have similarities in the factors causing pedophile behavior. The main common factors of the three participants in this study are the lack of affection from the family, especially the father figure, low self-esteem, failure to have a relationship with a partner, feeling disappointed or frustrated, consumption of pornographic content, and the inability to control sexual desire. Meanwhile, the different factors of the three participants were poor environment, having a less harmonious family background, relatively low level of economy, and education. Having-teen sexual experiences or have been victims of sexual harassment, having been physically abused or the victims of bullying and having sexual disorders can also be the factors. In addition, all three participants had a lack of sex education or understanding related to participants' cognitive aspects. There are also some factors related to affective aspects, namely feelings of guilt or even feeling of satisfaction after these three participants engage in inpedophile behavior. The conative aspect includes other factors such as the consumption of pornographic content, and the way participants give the lure to the victims and their threats, as well as how to perform pedophile behavior by inserting genitals into the victim's anus and then touching, pressing down the victim's genitals.
\end{abstract}

Keywords: Pedophilia, Factors, Psychological Dynamics

\begin{abstract}
ABSTRAK
Penelitian ini bertujuan untuk mengungkap bagaimana dinamika psikologis yang terjadi pada pelaku pedofilia. Fokus penelitian yang digunakan di dalam penelitian ini adalah tentang apa faktor-faktor yang menjadi penyebab perilaku pedofilia pada pelaku. Penelitian ini menggunakan metode kualitatif dengan pendekatan studi kasus. Hasil penelitian menunjukkan bahwa pelaku merupakan orang yang dikenal korban, yaitu tetangga dan guru. Secara umum ketiga partisipan memiliki kesamaan dalam faktor yang menjadi penyebab perilaku pedofilia. Faktor utama yang sama dari ketiga partisipan dalam penelitian ini yaitu kurangnya kasih sayang dari keluarga terutama sosok ayah, merasa harga diri rendah, gagalnya menjalin hubungan dengan pasangan, memiliki rasa kecewa atau frustasi, konsumsi konten pornografi, dan ketidakmampuan mengontrol hasrat seksual. Sedangkan faktor yang berbeda dari ketiga partisipan yaitu lingkungan yang kurang baik, latar belakang keluarga yang kurang harmonis, relatif rendahnya taraf ekonomi dan pendidikan. Memiliki pengalaman seksual pra-remaja atau pernah menjadi korban pelecehan seksual, pernah mengalami kekerasan secara fisik serta korban bullying, dan memiliki kelainan seksual. Selain itu, ketiga partisipan kurang mendapat
\end{abstract}

\footnotetext{
${ }^{1}$ Pambudi Rahardjo, Universitas Muhammadiyah Purwokerto. pambimb@gmail.com

${ }^{2}$ Kaniya Puri, Universitas Muhammadiyah Purwokerto.kaniyapuri03@gmail.com
} 
pendidikan atau pemahaman mengenai seks yang berkaitan dengan aspek kognitif partisipan. Faktor yang berkaitan dengan aspek afektif yaitu perasaan bersalah atau bahkan merasa puas yang dirasakan oleh ketiga partisipan setelah melakukan perilaku pedofilia. Sedangkan untuk aspek kognitif meliputi faktor lain seperti konsumsi konten pornografi, dan cara partisipan yang memberi iming-imingi kepada korban dan ancamannya, serta cara melakukan perilaku pedofilia dengan memasukkan alat kelamin ke anus korban dan meraba, menekan-nekan alat kelamin korban.

Kata Kunci : Pedofilia, Faktor Penyebab, Dinamika Psikologis

\section{PENDAHULUAN}

Perilaku seks yang normal adalah yang dapat menyesuaikan diri, bukan saja dengan tuntutan masyarakat tetapi juga dengan kebutuhan individu mengenai kebahagiaan dan pertumbuhan, yaitu perwujudan diri sendiri atau peningkatan kemampuan individu untuk mengembangkan kepribadiannya menjadi lebih baik (Maramis, 2004). Kartono (2003) mengemukakan bahwa ketidakwajaran seksual mencakup perilaku seksual atau fantasi-fantasi seksual yang dapat diarahkan pada pencapaian orgasme lewat relasi di luar hubungan kelamin heteroseksual, dengan jenis kelamin yang sama atau dengan partner yang belum dewasa, serta bertentangan dengan norma-norma tingkah laku seksual dalam masyarakat yang bisa diterima secara umum. Abnormalitas dalam hal dorongan seksual salah satunya adalah sexual abuse terhadap anak yang dapat berupa perlakuan pra kontak seksual antara anak dengan orang yang lebih dewasa (incest, perkosaan, pedofilia, dan eksploitasi seksual).

Berdasarkan informasi yang didapat dari salah satu polisi pada unit PPA (Pelayanan Perempuan dan Anak) Polres Cilacap, Jawa Tengah. Kasus perlindungan anak yang terjadi sepanjang 2012 sampai 2019 sebanyak 135 kasus. Sedangkan untuk kasus pedofilia sendiri terdapat 3 kasus selama tahun 2019. Menurut peneliti, kasus pedofilia merupakan kasus yang menarik karena tindakan yang dilakukan pelaku merupakan perilaku seks yang tidak wajar dan tidak sesuai dengan norma yang berlaku, terlebih korbannya adalah anak-anak dibawah umur yang memiliki hak untuk tumbuh dan berkembang secara optimal. Hal tersebut membuat beberapa penelitian sebelumnya mengkaji dari perspektif korban. Berbeda dengan penelitian yang dilakukan, kali ini peneliti mengkaji dari sisi pelaku. Penelitian ini penting dilakukan karena untuk mengetahui faktor penyebab yang menjadi latar belakang pelaku melakukan perilaku pedofilia.

Pedofilia adalah pelampiasan hawa nafsu seksual dengan mengambil anak-anak di bawah umur sebagai objek. Hal tersebut dilakukan oleh kaum laki-laki maupun perempuan. Kebanyakan kaum pedofilia adalah pria dengan korban anak perempuan yang disebut pedofilia heteroseksual sedangkan dengan anak laki-laki disebut dengan pedofilia homoseksual. Menurut Probosiwi (2015) pedofilia merupakan kelainan seksual dimana seseorang menyukai melakukan hubungan seksual dengan anak. Menurut Maslim (2013) pedofilia merupakan preferensi seksual yang cenderung berulang dan menetap terhadap anak-anak, biasanya pra pubertas atau awal masa pubertas, baik laki-laki maupun perempuan. Termasuk dewasa yang mempunyai preferensi partner seksual dewasa, tetapi karena mengalami frustrasi yang kronis atau penyebab lainnya yang menghambat untuk mencapai hubungan seksual yang diharapkan, maka kebiasaannya beralih kepada anak-anak sebagai gantinya. Menurut Yogatama pedofilia tidak hanya sebuah perbuatan (behavior), namun juga sebuah sikap (attitude) yang menyimpang sehingga tendensi suka pada anak-anak demi kepuasan seksual dari seseorang dewasa (dalam Ruhma, 2012). 
Karakteristik pedofilia dalam Diagnostic and Statistical Manual of Mental Disorders yaitu berulang, intens, dorongan seksual dan gairah seksual fantasi, dengan durasi setidaknya enam bulan, melibatkan aktivitas seksual dengan anak pra pubertas. Usia anak umumnya berusia 13 tahun ke bawah. Usia orang dewasa (pelaku) ditetapkan pada usia 16 tahun atau lebih dan setidaknya 5 tahun lebih tua dari anak (korban) (Lanning, 1992). Menurut Khaidir (2007) karakteristik pedofilia berdasarkan klasifikasinya yaitu bagi pelaku pedofilia heteroseksual, dia memiliki status sosio-ekonomi, pendidikan dan pekerjaan yang lebih rendah dibandingkan dengan populasi yang normal. Mengalami kesulitan dalam melakukan kontak kepada sesama manusia, mereka merasa malu dan bertingkah laku yang tidak lazim. Selain itu, umumnya pelaku pedofilia tidak memiliki riwayat kriminal, serta pada umumnya pelaku pedofilia mengalami pernikahan yang cenderung bermasalah (Khaidir, 2007).

Cahyono et al (2018) menyatakan bahwa karakteristik bagi pelaku pedofilia homoseksual ialah a) memiliki riwayat perilaku homoseksual sebelum menjadi pelaku; b) tertarik kepada sesama jenis yang usianya masih anak-anak. Riwayat homoseksual ini bukan saja sebagai pelaku, tetapi juga ketika seseorang menjadi korban dari keganasan homoseksual dapat menjadikan dirinya bertindak sebagai pedofilia yang homoseksual. (Probosiwi \& Daud, 2015) mengatakan bahwa pelaku pedofilia tidak hanya berjenis kelamin laki-laki, tetapi juga perempuan. Praktiknya, perilaku ini bisa dilakukan oleh laki-laki terhadap anak-anak laki-laki atau perempuan, begitu juga pelaku perempuan bisa melakukan hal yang sama dengan seperti pelaku laki-laki.

Heriyono (Wardhani \& Kurniasari, 2016) menyatakan penyebab seseorang menjadi pedofil karena memiliki trauma masa lalu, kurangnya kemampuan bersosialisasi, merasa harga diri rendah, dan faktor ekonomi. (Aisyah, 2017) mengatakan bahwa faktor penyebab penyimpangan seksual dibagi menjadi faktor resiko dan faktor protektif. Faktor resiko mencakup lingkungan yang kurang baik, dan konsumsi pornografi. Sedangkan faktor protektif penyebab penyimpangan seksual yaitu nilai yang diyakini, motivasi, persepsi, kemampuan untuk menolak, pemberian pendidikan seks, dan komunikasi yang baik dengan orang tua.

Sedangkan menurut Walgito (2010) aspek psikologis yang terdapat pada diri manusia yang mempengaruhi dan membentuk perilaku dalam kehidupan sehari-hari serta berkaitan dengan dinamika psikologis, yaitu : aspek kognitif merupakan komponen yang berkaitan dengan pemahaman, pengetahuan, pandangan, dan keyakinan yang berhubungan dengan persepsi seseorang terhadap sebuah objek perilaku atau kejadian yang sedang dialami. Aspek afektif (aspek emosional) melibatkan perasaan atau emosi, reaksi emosional terhadap suatu objek akan membentuk sikap positif atau negatif terhadap objek tersebut (Zuchdi, 1995). Selanjutnya yaitu aspek konatif (perilaku) berhubungan dengan kecenderungan untuk bertindak terhadap suatu objek. Aspek ini menunjukkan besar kecilnya kecenderungan bertindak atau berperilaku, serta menunjukkan bagaimana perilaku manusia terhadap lingkungan sekitar. Keterkaitan antara berbagai aspek psikologis yang ada dalam diri seseorang dengan faktor-faktor dari luar yang mempengaruhinya didefinisikan sebagai dinamika psikologis (Saptoto, 2009). Fokus pada penelitian ini yaitu bagaimana dinamika psikologis pelaku pedofilia berdasarkan faktor-faktor penyebab dan aspek dinamika psikologisnya.

\section{METODE PENELITIAN}

Penelitian ini merupakan penelitian kualitatif dengan menggunakan pendekatan studi kasus yang penelitiannya mengeksplorasi kehidupan nyata, sistem terbatas kontemporer (kasus) atau beragam sistem terbatas (dari berbagai kasus), melalui pengumpulan data yang detail dan mendalam yang melibatkan beragam sumber informasi atau sumber informasi yang majemuk (seperti pengamatan, wawancara, audio visual, dokumen, dan berbagai laporan) (Creswell, 2015). Dalam penelitian ini, teknik yang digunakan adalah Purposive Sampling 
adalah teknik pengambilan sampel sumber data dengan pertimbangan tertentu (Sugiyono, 2017). Partisipan penelitian yang diteliti yaitu terdiri dari partisipan primer yang merupakan pelaku kasus pedofilia di Lapas II B Cilacap dan partisipan sekunder yaitu penyidik dari Polres Cilacap yang menangani kasus pelaku pedofilia dan tetangga sekitar pelaku yang mengetahui keadaan pelaku kasus pedofilia.

Teknik pengumpulan data yang digunakan dalam penelitian ini yaitu wawancara dan dokumentasi. Menurut Moleong, wawancara adalah percakapan dengan maksud tertentu, percakapan itu dilakukan oleh dua pihak yaitu pewawancara (interviewer) atau yang mengajukan pertanyaan dan terwawancara (interviewee) atau yang memberikan jawaban atas pertanyaan yang diajukan (Moleong, 2017). Dokumentasi merupakan catatan peristiwa yang sudah berlalu berbentuk tulisan, gambar, atau karya-karya monumental dari seseorang yang berupa identitas dan daftar riwayat hidup partisipan, keterangan kasus dari pihak Polres Cilacap dan Lembaga Pemasyarakatan (LAPAS) II B Cilacap.

\section{HASIL}

Ketiga partisipan dalam penelitian ini memiliki beberapa faktor penyebab perilaku pedofilia yang sama. Sejak remaja, ketiga partisipan kurang mendapatkan pendidikan mengenai seks dari orang tua dimana hal tersebut berkaitan dengan aspek kognitif yang meliputi pemahaman mengenai seks pada diri partisipan. Partisipan AA, YE, dan N juga merasa kurang mendapat kasih sayang dari keluarga terutama sosok ayah sehingga partisipan tumbuh menjadi individu yang memiliki harga diri rendah. Selain itu, ketiga partisipan pernah mengalami gagal dalam menjalin hubungan dengan pasangan. Kegagalan tersebut membuat ketiga partisipan tidak merasakan keharmonisan atau kepuasan dalam hubungan yang dijalinnya sehingga memunculkan perasaan kecewa, dan frustrasi. Faktor penyebab tersebut berkaitan dengan aspek psikologis dalam diri partisipan yaitu aspek afektif yang meliputi perasaan dalam diri partisipan.

Keadaan tersebut membuat dua dari tiga partisipan akhirnya memilih untuk mengkonsumsi konten pornografi. Konten pornografi membuat partisipan tidak mampu mengontrol hasrat seksual yang muncul setelah menontonnya. Ketidakmampuan mengontrol hasrat seksual tersebut membuat partisipan melampiaskannya kepada anak-anak yang berada di sekitarnya. Sasaran atau anak yang menjadi korban serta cara ketiga partisipan dalam membujuk dan melakukan perilaku pedofilia tersebut berbeda-beda seperti yang sudah dijelaskan sebelumnya. Untuk hal itu berkaitan dengan aspek konatif yaitu aspek yang meliputi cara partisipan melakukan perilaku pedofilia. Di bawah ini merupakan gambaran atau skema faktor-faktor yang menjadi penyebab perilaku pedofilia pada ketiga partisipan : 


\section{Gambar 6. Skema Faktor Penyebab Perilaku Pedofilia pada Pelaku}

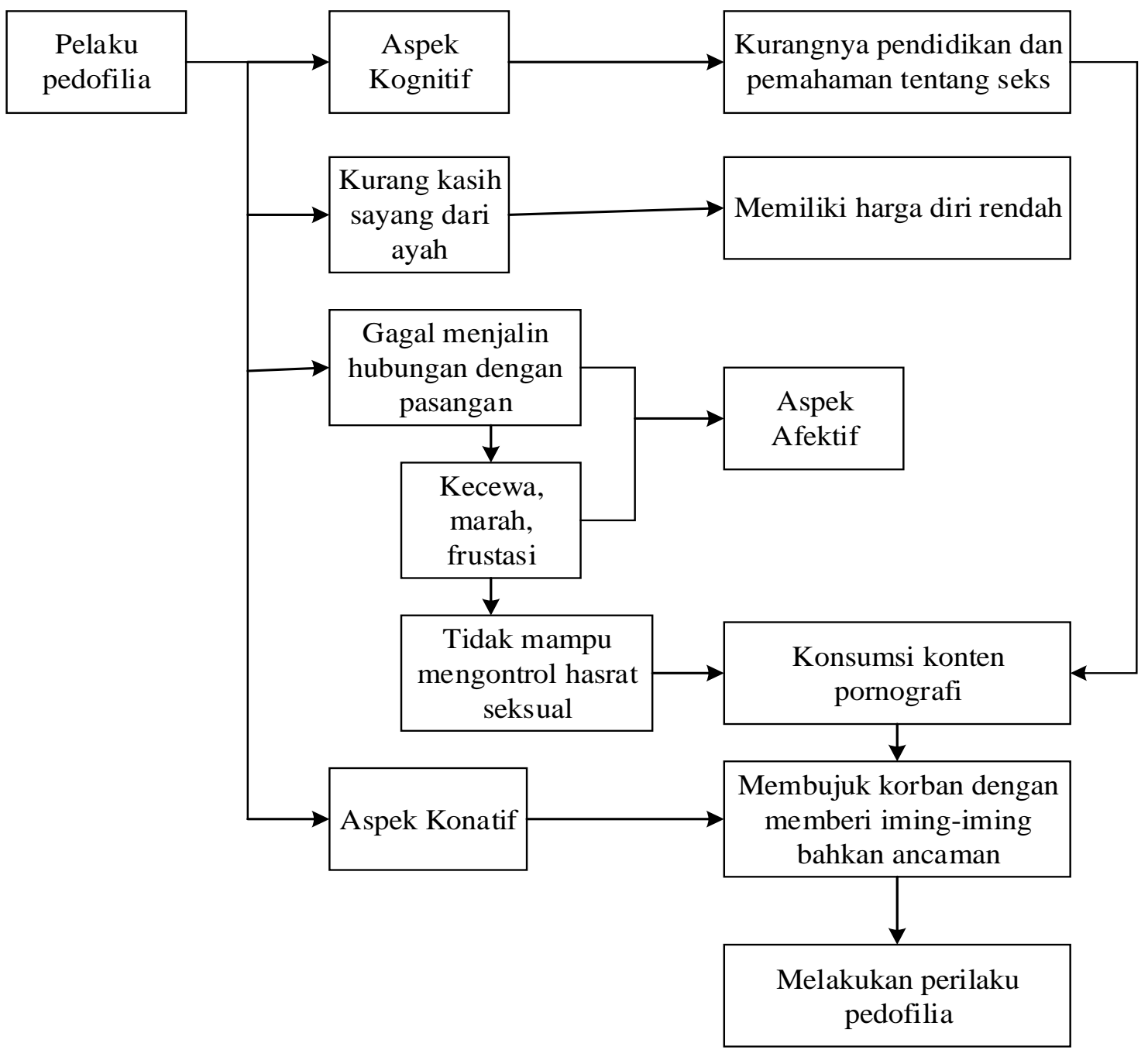

\section{PEMBAHASAN}

Pada penelitian ini, partisipan pertama dan kedua merupakan tetangga dari korban, sedangkan hubungan antara partisipan ketiga dan korbannya yaitu guru dan siswa perempuan. Hubungan antara ketiga partisipan dengan korbannya tersebut bukan berasal dari keluarga inti korban, melainkan orang asing yang dikenal korban dan biasa berinteraksi dengan korban. Menurut McCaghy bahwa mayoritas pola pelecehan seksual yang terjadi pada anak adalah pelaku dengan interaksi tinggi (Prasetyo, 2018). Diperkuat oleh pendapat Lanning yang mengatakan bahwa banyak kasus pelecehan seksual anak pelakunya adalah anggota keluarga, guru, tetangga, dan orang terdekatnya (Prasetyo, 2018).

Pelaku yang melakukan tindakan pedofilia tersebut tentu memiliki latar belakang atau faktor penyebab yang berbeda-beda. Salah satu temuan dari penelitian yang telah dilakukan yaitu dua dari ketiga partisipan berada pada taraf ekonomi menengah ke bawah dan pendidikan yang relatif rendah. Penelitian sebelumnya yang dilakukan oleh Wardhani (2016) mengenai "Pedofilia Sebagai Ancaman Tersembunyi Bagi Anak" mengatakan bahwa salah satu faktor penyebab seseorang menjadi pedofil yaitu faktor ekonomi. Pelaku pedofilia kebanyakan berasal dari kalangan sosial ekonomi rendah, sebagian bahkan tidak memiliki pekerjaan, serta 
ditambah dengan tingkat pendidikan yang umumnya kurang memadai, mereka sulit menemukan cara penyelesaian masalah yang efektif.

Satu dari ketiga partisipan dalam penelitian ini pernah mengalami pelecehan seksual pada saat usia 10 tahun atau pernah menjadi korban. Temuan ini didukung oleh teori yang disampaikan Bagley bahwa anak laki-laki dan remaja yang telah mengalami pelecehan seksual berada pada resiko yang lebih besar di tahun-tahun selanjutnya menjadi pelaku pelecehan seksual anak-anak atau remaja. Pandangan ini digambarkan sebagai siklus "korban-ke-pelaku" (Lee, 2002). Selain pelecehan seksual, terdapat juga partisipan yang mengalami kekerasan fisik dan dilakukan oleh kakak tirinya saat usia 10 tahun. Temuan ini diperkuat oleh pendapat Seghorn yang mengatakan bahwa sejarah kekerasan fisik masa kanak-kanak biasanya ditemukan di kalangan pelanggar seks (Lee, 2002).

Meskipun masih sangat sedikit penelitian yang meneliti hubungan khusus antara jenis kekerasan fisik ini dan jenis pelanggar seks tertentu namun pendapat ini dapat dikatakan cukup relevan. Marshall dan Barbaree menambahkan bahwa pengalaman sosialisasi yang buruk, seperti pengasuhan yang penuh kekerasan, bertanggung jawab untuk pengembangan perasaan dendam dan permusuhan yang kuat, yang merupakan elemen penting dalam pelanggaran seksual (Lee, 2002). Peristiwa yang terjadi selanjutnya saat partisipan berusia 9-10 tahun yaitu bullying, partisipan pernah menjadi korban bully oleh teman-temannya. Studi yang dilakukan Brockenbrough menunjukkan bahwa terdapat hubungan antara korban bullying dengan kekerasan dan perilaku agresif (Hidayati, 2012).

Ketiga partisipan merasa kurang mendapat kasih sayang dari keluarga terutama sosok ayah. Hasil tersebut diperkuat oleh teori yang menyatakan bahwa minimnya kehangatan hubungan emosional antar anggota keluarga dapat memicu seseorang mengalami gangguan orientasi seksual (Dhawan \& Marshall, 2003). Wibhowo \& Pascario (2014) menambahkan bahwa kemungkinan terjadi penyimpangan seksual yang dipengaruhi oleh hubungan yang jauh dengan ayah dan kakak serta menikmati waktu-waktu sendiri. Bowlby (2001) juga menjelaskan bahwa seorang anak yang berkembang pada kondisi emosi yang tidak aman dan nyaman dalam hubungan emosionalnya dengan orang tua sejak usia dini akan tumbuh menjadi individu yang sarat dengan segala permasalahan yang berkaitan dengan gangguan psikologis.

Hal tersebut juga menjadikan partisipan tumbuh menjadi individu yang merasa bahwa harga dirinya rendah sehingga merasa minder dan tidak memiliki kelebihan dalam dirinya. Hasil tersebut diperkuat oleh pendapat Heriyono yang mengatakan bahwa salah satu faktor yang menjadi penyebab perilaku pedofilia yaitu merasa harga diri rendah dimana mereka (pelaku) merasa tidak memiliki kelebihan, atau merasa gagal dibandingkan pasangan atau teman-temannya.Orang yang merasa rendah diri juga mudah mengalami depresi dan kecemasan. Kondisi ini, melakukan pelecehan seksual ataupun kekerasan seksual terhadap anak dijadikan cara melepaskan ketegangan (Wardhani, 2016). Selain faktor yang telah dijelaskan di atas, ketiga partisipan juga pernah mengalami kegagalan dalam menjalin hubungan dengan pasangannya yang mengakibatkan muncul perasaan tidak puas dalam hubungan dan kecewa serta frustasi. Hasil temuan tersebut diperkuat dengan hasil penelitian yang dilakukan oleh Khaidir (2007) yang mengatakan bahwa pada umumnya pelaku pedofilia mengalami pernikahan yang cenderung bermasalah dan tidak harmonis. Ketidakharmonisan hubungan dengan pasangan merupakan salah satu pemicu untuk mencari upaya alternatif dalam memuaskan kebutuhan biologis (Wardhani, 2016).

Karena hal tersebut, dua dari tiga partisipan dalam penelitian ini terbiasa mengkonsumsi atau menonton konten pornografi, bahkan salah satu partisipan terbiasa menonton konten pornografi tentang gay sex kid. Hasil penelitian tersebut sesuai dengan pendapat Seto dengan judul penelitian "Identifying Pedophilia" yang mengatakan bahwa banyak pelaku pedofilia juga memiliki beberapa gambar anak-anak pra-remaja dan sering menggunakan/mengkonsumsi pornografi anak. Pelanggaran pornografi anak dapat dianggap 
sebagai indikator pedofilia (Bridge \& Nesrin, 2018). Setelah menonton konten pornografi dan tidak mampu melampiaskan hasrat seksualnya, maka partisipan menjadikan anak sebagai ganti untuk memuaskan hasrat seksual yang tidak tersalurkan tersebut. Hasil tersebut sesuai dengan teori yang disampaikan oleh Maslim (2013) bahwa pedofilia termasuk individu dewasa yang mempunyai preferensi partner seksual dewasa, tetapi karena mengalami frustasi yang kronis atau penyebab lainnya yang menghambat untuk mencapai hubungan seksual yang diharapkan, maka kebiasaannya beralih kepada anak-anak sebagai gantinya.

\section{KESIMPULAN}

Kesimpulan dari penelitian ini bahwa secara umum ketiga partisipan memiliki kesamaan dan perbedaan dalam faktor yang menjadi penyebab perilaku pedofilia. Faktor utama yang sama dari ketiga partisipan dalam penelitian ini yaitu kurangnya kasih sayang dari keluarga terutama sosok ayah, merasa harga diri rendah, gagalnya menjalin hubungan dengan pasangan, memiliki rasa kecewa atau frustasi, dan ketidakmampuan mengontrol hasrat seksual yang berkaitan dengan aspek afektif.

Sedangkan faktor penyebab yang berbeda dari ketiga partisipan yaitu lingkungan yang kurang baik, latar belakang keluarga yang kurang harmonis, relatif rendahnya taraf ekonomi dan pendidikan. Memiliki pengalaman seksual pra-remaja atau pernah menjadi korban pelecehan seksual, pernah mengalami kekerasan secara fisik serta korban bullying, dan memiliki kelainan seksual. Selain itu, ketiga partisipan kurang mendapat pendidikan atau pemahaman mengenai seks yang berkaitan dengan aspek kognitif partisipan. Faktor yang berkaitan dengan aspek afektif yaitu perasaan bersalah atau bahkan merasa puas yang dirasakan oleh ketiga partisipan setelah melakukan perilaku pedofilia. Sedangkan untuk aspek konatif meliputi faktor lain seperti konsumsi konten pornografi, dan cara partisipan yang memberi iming-iming kepada korban dan ancamannya, serta cara melakukan perilaku pedofilia dengan memasukkan alat kelamin ke anus korban dan meraba, menekan-nekan alat kelamin korban.

Saran

Saran bagi peneliti selanjutnya agar menggambarkan lebih luas mengenai dampak psikologis yang dialami oleh pelaku setelah melakukan perilaku pedofilia. Meneliti sejauh mana lingkungan berperan penting dalam terbentuknya perilaku pedofilia, karena berdasarkan data kabupaten Cilacap memiliki angka yang cukup tinggi untuk kasus pedofilia dan perlindungan anak. Bagi instansi terkait dapat mengadakan program rutin berupa sosialisasi kepada masyarakat mengenai bahaya pedofilia untuk anak-anak dan kejahatan seksual lainnya sebagai upaya preventif agar kasus pedofilia dan kejahatan seksual yang mengancam anak tidak semakin meningkat. Memiliki program pendampingan secara psikologis kepada pelaku pedofilia maupun pelaku kejahatan seksual lainnya sehingga ketika pelaku selesai menjalani hukuman, tidak hanya sisi sosial yang menjadi lebih baik tetapi juga dari sisi psikis atau mental.

\section{DAFTAR PUSTAKA}

Aisyah, S. (2017). Studi Kasus Penyimpangan Perilaku Seksual Pada Remaja Tunalaras Tipe Conduct Disorder. 18-19.

Bowlby, W. A. (2001). A Meta-Analytic Examination of Assumed Properties of Child Sexual Abuse Using College Samples. Psychological Bulletin, 2(4), 22-53.

Bridge, E. N., \& Nesrin, D. (2018). Identifying Pedophila. Life Skills Journal of Psychology, 2(4), 215-222.

Cahyono, H., Suhono, S., \& Khumairo, A. (2018). Pendidikan Karakter Bagi Pelaku Pedofilia 
(Sebuah Strategi Dalam Mengatasi Amoral). JMKSP (Jurnal Manajemen, Kepemimpinan, Dan Supervisi Pendidikan), 3(1), 1-19. https://doi.org/10.31851/jmksp.v3i1.1519

Creswell, J. W. (2012) Research Design. Yogyakarta: Pustaka Pelajar.

Dhawan S, Marshall WL. (2003). Sexual Abuse Histories of Sexual Offenders. Journal of Psychology. (8), 7-15.

Hidayati, Nurul. (2012). Bullying pada Anak: Analisis dan Alternatif Solusi. Insan. 14 (1), 4148.

Kartono, Kartini. (2003). Patologi Sosial Jilid 1. Jakarta: PT. Raja Grafindo Persada.

Khaidir, M. (2007). Penyimpangan Seks (Pedofilia). Jurnal Kesehatan Masyarakat, 1(2), 8389.

Lanning, K. V. (1992). Child Molesters : A Behavioral Analysis For Law Enforcement Officer Investigating Cases of Child Sexual Exploitation (3rd ed.). Behavioral Science Unit Federal Bureau of Investigation FBI Academy.

Lee, Joseph. K. P., \& Henry J. Jackson., \& Pip Pattison., \& Tony Ward. (2002). Developmental Risk Factors for Sexual Offending. Child Abuse \& Neglect. (26), 73-92.

Maramis.(2004). Ilmu Kedokteran Jiwa. Malang: Erlangga University Press.

Maslim, R. (2013). Buku Saku Diagnosis Gangguan Jiwa Rujukam Ringkas dari PPDGJ-III dan DSM-5. Jakarta: PT. Nuh Jaya.

Moleong, L. J. (2017). Metodologi Penelitian Kualitatif Edisi Revisi. PT. Remaja Rosdakarya.

Prasetyo, Ratna Azis. (2018). Pedophilia (Ditinjau dari Aspek Pelaku, Kriminalitas, dan Perlindungan Anak). Jurnal Harkat: Media Komunikasi Gender. 14 (2), 121-128.

Probosiwi, R., \& Daud, B. (2015). Pedofilia dan Kekerasan Seksual: Masalah dan Perlindungan Terhadap Anak. Sosio Informa, 1(1), 29-40.

Ruhma, Misfatur., \& Erni Agustina Setiowati. (2017). Pengetahuan Tentang Pedofilia dan Kecemasan Terhadap Kekerasan Seksual Pada Orang Tua Dengan Anak Berkebutuhan Khusus. Proyeksi. 12 (2), 59-68.

Saptoto, R. (2009). Dinamika Psikologis Nerimo Dalam Bekerja: Nerimo Sebagai Motivator atau Demotivator?.Jurnal Psikologi Indonesia. 6 (2), 131-137.

Sugiyono. (2017). Metode Penelitian Kuantitatif, Kualitatif, dan R\&D. Bandung: Alfabeta.

Walgito, Bimo. (2010). Pengantar Psikologi Umum. Yogyakarta: Penerbit Andi Yogyakarta.

Wardhani, Y. F., \& Kurniasari, A. (2016). Pedofilia Sebagai Ancaman Tersembunyi Bagi Anak (Pedophilia As a Hidden Threat of Children). Sosio Informa, 2(3), 314-322.

Wibhowo, C. \& Pascario, N. S. Y. (2014). Analisis Dinamika Kepribadian Gay Menggunakan Teknik Wartegg. Jurnal Psikodimensia, 13 (2), 1-13.

Zuchdi, Darmiyati. (1995). Pembentukan Sikap. Jurnal Cakrawala Pendidikan. 3, 51-63. 